\title{
NUMERICAL INVESTIGATION OF DESIGN PARAMETERS EFFECTS ON PERFORMANCE OF COOLING SYSTEM DESIGNED FOR A LITHIUM-ION CELL
}

\author{
Mohammad Alipour ${ }^{1, *}$, Riza Kizilel ${ }^{1}$
}

\begin{abstract}
A 3D numerical approach using the Finite Element Method (FEM) is applied to model the thermal behavior of multilayer $20 \mathrm{Ah} \mathrm{LiFePO}_{4} / \mathrm{Graphite}$ cell and to design a cooling system. A three-dimensional multilayer cell model with heterogeneous thermal properties for the various cell layers is developed to study the effects of design parameters on cooling performance of mini-channel aluminum plates. As design parameters, effects of channel width, a number of channel passes, inlet mass flow rate, and heat transfer medium were considered. Using the optimized parameters, the cooling performance of water-cooling and air-cooling systems were compared. The results showed that the designed cooling system provided good cooling performance in controlling the temperature rise and uniformity. Inlet mass flow rate was the main influential parameter in controlling the cooling performance. The optimum number of channel passes was found to be seven passes. Channel width mainly controlled the pressure drop and had minor effects on temperature. At higher discharge current rates, the water-cooling system showed better cooling performance in dropping the maximum temperature and making uniform surface and inner temperature profile. Moreover, pressure drop, and power consumption rates become significantly lower for water cooling system.
\end{abstract}

\section{Keywords: Multilayer Cell, Thermal Management, Air-Cooling System, Water-Cooling System}

\section{INTRODUCTION}

The environmental issues associated with fossil fuels and nuclear energy necessitate usage of renewable energy sources. The main advantages of renewable technologies as clean energy sources are minimized environmental impacts and minimum secondary waste production. However, renewable energy sources are limited, and they are not sustainable in most regions. Therefore, high efficiency energy storage systems are needed to store the produced energies [1-3]. Super capacitors and batteries play a crucial role in the storage of the electrical energy both in largescale global energy systems and in more small-scale energy systems such as mobile devices. Besides mobile electric and electronic devices, expanding considerations have been paid to electrical vehicles (EVs) and hybrid electrical vehicles in terms of energy storage $[4,5]$.

The popularity of Lithium ion batteries as rechargeable devices is growing due to their applications in electrochemical energy storage (EES) systems and electrical vehicles (EVs). However, these batteries suffer from some thermal issues. The temperature of a cell greatly affects the performance efficiency and cycle-life of lithium ion batteries [6-8]. High internal resistance at low temperatures as well as active material and electrolyte decomposition at high temperatures result in capacity fade [9-11]. Uncontrolled temperature elevation inside the battery due to selfaccelerated exothermic side reactions results in thermal runaway [10, 12]. In addition, small non-uniformity of temperature significantly affects performance and the cycle-life of the batteries [13]. Therefore, an appropriate thermal management system is necessary for Li-ion battery packs and modules especially within high power energy storage devices and systems $[14,15]$.

Thermal management of batteries include either cooling the battery packs at higher operating temperatures or heating them at lower operating temperatures [16]. Choosing a proper cooling method to keep the temperature at an optimal range is essential for increasing safety, extending the battery life, and reducing costs [17]. The thermal management can be broadly classified as air-cooling, liquid-cooling, and phase change material-based (PCM) cooling $[18,19]$. There has been much research done with regard to thermal management of lithium batteries, both on the 
numerical and experimental front. However, most researchers use single-layer cell or lumped model in designing a thermal management system to save in computing time [20,21]. In the lumped model, the battery cell is considered as a single solid with a spatially uniform temperature distribution, and the temperature is assumed to be only as a function of time (t). In other words, thermal conductivity (k) of the solid is assumed to be infinite and negligible temperature gradient is observed [22]. For instance, Ping et al.[23] modeled the cell by a solid structure formed with homogeneous layers to study the effect of the environment or/and airflow cooling on the behavior of the cell. Liu et al.[24] developed a 3D lumped model in which the cell structure is considered as an integrated and homogeneous element with the uniform thermal properties and distribution. Chen et al.[25] used a single-layer cell model to compare different cooling methods for lithium ion battery cells. Qian et al. [26] analyzed a thermal performance of a lithium ion battery thermal management system by using a mini-channel cooling system and cells developed by the lumped model. The Above methods, however, neglect the effects of cell multilayer structure on temperature distribution along the battery cell as the thermal properties of different layers would differ and would significantly influence the conductive heat transfer within the cell. Moreover, total internal impedance of the cell is affected by the electrodes thickness [18]. In this approach, Chen et al. [27] studied the thermal behavior of the lumped-model and multilayer-model. They showed that the temperature non-uniformity factor of the multilayer-model is bigger than that of the lumped model, and they got more precise results from the multilayer model. Goutam et al. [28] coupled a 2D potential distribution model with the 3D multilayer thermal model, and they reproduced spatial temperature non-uniformity with high accuracy. In our previous work, we showed the superiority of the multilayer-model in predicting the thermal behavior of $20 \mathrm{Ah} \mathrm{LiFePO}_{4}$ batteries [29].

Therefore, in this work, a multilayer cell model instead of a lumped model or a single-layer model is used for designing a thermal management system. Electrochemical and thermal performance of the developed model are validated using the experimental measurements. Mini-channel cold plates are used as the thermal management system. Then, the effects of design parameters on cooling performance of the cooling plates are investigated. Cooling performance of passive water-cooling system (WCS) and air-cooling system (ACS) are compared using the optimized parameters. Based on the results, the WCS shows better cooling performance in terms of decreasing temperature rise, temperature uniformity, and total power consumption.

\section{MODEL AND METHODOLOGY}

\section{GOVERNING EQUATIONS}

The model includes the mathematical equations used for both the cell and the cooling plates. The electrochemical-thermal equations which are used for the Li-ion cell are listed in Table 1. These equations consist of the transient conservation of the energy, charges, and ions in the solid and liquid phase. All the derived partial differential equations are solved numerically using the COMSOL. Anisotropic heat conduction with cross-plane and in-plane thermal conductivities is considered for the composite material used in the positive and negative electrodes. The cross-plane thermal conductivity corresponds to the thickness direction, whereas, the in-plane thermal conductivity corresponds to the width and length directions.

Table 1. Governing equations used in the electrochemical-thermal model

\begin{tabular}{|c|c|c|}
\hline Process & Equation & \\
\hline $\begin{array}{l}\text { Material balance, solid } \\
\text { phase }[30-32]\end{array}$ & $\begin{array}{r}\frac{\partial c_{s, i}}{\partial t}=\frac{1}{r^{2}} \frac{\partial}{\partial r}\left(r^{2} D_{s, i} \frac{\partial c_{s, i}}{\partial r}\right) \\
\left.\frac{\partial c_{s, i}}{\partial r}\right|_{r=0}=0 ;-\left.D_{s, i} \frac{\partial c_{s, i}}{\partial r}\right|_{r=R_{S}}=\frac{i_{l o c}}{a_{s} F} ;(\mathrm{i}=\mathrm{ne}, \mathrm{pe})\end{array}$ & (1) \\
\hline $\begin{array}{l}\text { Material balance, liquid } \\
\text { phase }[30-32]\end{array}$ & $\begin{aligned} \varepsilon_{e} \frac{\partial c_{e}}{\partial t} & =\nabla \cdot\left(D_{e}^{e f f} \nabla c_{e}\right)+\frac{a_{s} i_{l o c}}{F}\left(1-t_{+}\right) \\
-\left.\nabla \cdot c_{e}\right|_{n e / c c^{-} \& p e / c c^{+}} & =0 ;-\left.\nabla \cdot c_{e}\right|_{n e / s p}=-\left.\nabla \cdot c_{e}\right|_{p e / s p}\end{aligned}$ & (2) \\
\hline $\begin{array}{l}\text { Electron transport, solid } \\
\text { phase }[30-32]\end{array}$ & $\begin{array}{c}i_{s}=-\sigma_{s, e f f} \nabla \varphi_{s} \\
-\left.\sigma_{s, e f f} \nabla \cdot \varphi_{s}\right|_{n e / c c^{-} \& p e / c c^{+}}=i_{N, i} ;-\left.\sigma_{s, e f f} \nabla \cdot \varphi_{s}\right|_{n e / s p \& p e / s p}=0\end{array}$ & (3) \\
\hline
\end{tabular}


Journal of Thermal Engineering, Research Article, Vol. 6, No. 6, Special Issue 12, pp. 257-271, December, 2020

Table 2. Governing equations used in the electrochemical-thermal model (cont.)

\begin{tabular}{|c|c|c|}
\hline Process & Equation & \\
\hline $\begin{array}{l}\text { Ionic transport, liquid phase } \\
{[30-32]}\end{array}$ & $\begin{array}{c}i_{e}=-\kappa_{e f f} \nabla \varphi_{e}+\left(\frac{2 \kappa_{e f f} R T}{F}\right)\left(1+\frac{\partial \ln f}{\partial \ln c}\right)\left(1-t^{+}\right) \nabla \ln c_{e} \\
\left.\nabla \cdot \varphi_{e}\right|_{n e / c c^{-} \& p e / c c^{+}}=0\end{array}$ & (4) \\
\hline $\begin{array}{l}\text { Charge conservation, solid } \\
\text { phase [30-32] }\end{array}$ & $-\nabla . i_{s}-a_{s}\left(i_{l o c}+C_{d l}\left(\frac{\partial \varphi_{s}-\partial \varphi_{l}}{\partial t}\right)\right)=0$ & (5) \\
\hline $\begin{array}{l}\text { Charge conservation, liquid } \\
\text { phase [30-32] }\end{array}$ & $-\nabla \cdot i_{e}+a_{s} i_{l o c}=0$ & (6) \\
\hline $\begin{array}{l}\text { Local current density } \\
\text { (Butler - Volmer equation) } \\
\text { [30-32] }\end{array}$ & $i_{l o c}=i_{0}\left(\exp \left(\frac{\alpha_{a} F \eta}{R T}\right)-\exp \left(\frac{-\alpha_{c} F \eta}{R T}\right)\right)$ & (7) \\
\hline $\begin{array}{l}\text { Exchange current density } \\
\text { [30-32] }\end{array}$ & $i_{0}=F\left(k_{c}\right)^{\alpha_{a}}\left(k_{a}\right)^{\alpha_{c}}\left(c s, \operatorname{sur}_{s, \max }()^{\alpha_{a}}\left(c_{s, \text { sur }}\right)^{\alpha_{c}}\left(\frac{c}{c_{r e f}}\right)^{\alpha_{a}}\right)$ & (8) \\
\hline Over-potential [30-32] & $\eta=\varphi_{s}-\varphi_{l}-U_{e q}$ & (9) \\
\hline $\begin{array}{l}\text { Effective solid electrical } \\
\text { conductivity [30-32] }\end{array}$ & $\sigma_{s, e f f}=\varepsilon_{S}{ }^{1.5} \sigma_{s}$ & $(10)$ \\
\hline $\begin{array}{l}\text { Effective electrolyte ionic } \\
\text { conductivity [30-32] }\end{array}$ & $\kappa_{e f f}=\varepsilon_{e}{ }^{1.5} \sigma_{e}$ & (11) \\
\hline $\begin{array}{l}\text { Effective electrolyte ionic } \\
\text { diffusivity [30-32] }\end{array}$ & $D_{l, e f f}=\varepsilon_{l}^{1.5} D_{l}$ & $(12)$ \\
\hline \multirow[t]{2}{*}{$\begin{array}{l}\text { Potentials in collectors \& } \\
\text { tabs [31] }\end{array}$} & $\begin{array}{l}\left.\quad \nabla \cdot\left(-\sigma_{c c, i} \nabla \varphi_{c c, i}\right)\right|_{n e / c c^{-} \& p e / c c^{+}}=-i_{N, i} \\
i_{N, i}=0 \text { at the tabs; }\end{array}$ & (13) \\
\hline & $\begin{aligned} & n .\left.\left(-\sigma_{c c, i} \nabla \varphi_{c c, i}\right)\right|_{c c^{-} \& c c^{+}}=i_{a p p, i}=\frac{I_{a p p}}{N \times A_{t a b}} \\
& \varphi_{c c i}=0 \text { at the top of a negative tab }\end{aligned}$ & (14) \\
\hline Energy balance $[30,31]$ & $\begin{array}{c}\rho c_{p} \frac{\partial T}{\partial t}-\frac{\partial}{\partial x}\left(\lambda_{\perp} \frac{\partial T}{\partial x}\right)+\frac{\partial}{\partial y}\left(\lambda_{\perp} \frac{\partial T}{\partial y}\right)+\frac{\partial}{\partial z}\left(\lambda_{\perp} \frac{\partial T}{\partial z}\right)=Q_{\text {revv }}+Q_{\text {irrevv }}+Q_{o h m} \\
(i=x):-\left.\lambda_{\perp} \frac{\partial T}{\partial i}\right|_{x=0 \& x=L_{L} b a t t}=h_{i}\left(T_{s}-T_{\infty}\right) ; \\
(i=y, z):-\left.\lambda_{\perp} \frac{\partial T}{\partial i}\right|_{y=0 \& y=w \& z=0 \& z=h}=h_{i}\left(T_{s}-T_{\infty}\right)\end{array}$ & $(15)$ \\
\hline $\begin{array}{l}\text { Reversible entropic heat } \\
{[30-32]}\end{array}$ & $Q_{\text {revv }}=a_{s} i_{l o c} T \frac{\partial U_{e q}}{\partial T}$ & (16) \\
\hline $\begin{array}{l}\text { Irreversible reaction heat } \\
\text { (polarization heat) [30-32] }\end{array}$ & $Q_{\text {irrev }}=F a_{s} i_{\text {loc }}\left(\varphi_{s}-\varphi_{e}-U_{e q}\right)$ & (17) \\
\hline Ohmic heat [30-32] & $Q_{o h m}=-i_{s} \cdot \nabla \varphi_{s}-i_{e} \cdot \nabla \varphi_{e}-i_{c c, i} \cdot \nabla \varphi_{c c, i}$ & (18) \\
\hline
\end{tabular}

We further add the equations used for the cooling plates. These equations consist of the conservation of mass, momentum, and energy in the cooling system. The equation of continuity and momentum conversion of cooling fluid are as follows [26]:

$$
\begin{gathered}
\frac{\partial \rho}{\partial t}+\nabla \cdot(\rho \vec{v})=0 \\
\frac{\partial}{\partial t}(\rho \vec{v})+\nabla \cdot(\rho \vec{v} \vec{v})=-\nabla p
\end{gathered}
$$


The energy conversion equations of fluid and the cold plate are as follows [26]:

$$
\begin{gathered}
\frac{\partial}{\partial t}(\rho c T)+\nabla \cdot(\rho c \vec{v} T)=\nabla \cdot(k \nabla T) \\
\frac{\partial}{\partial t}\left(\rho_{p} c_{p} T_{p}\right)=\nabla \cdot\left(k_{p} \nabla T_{p}\right)
\end{gathered}
$$

Where $\rho, c, k, T, \vec{v}$ are the density, heat capacity, thermal conductivity, temperature, and velocity vector of fluid and $\rho_{p}, c_{p}, k_{p}, T_{p}$ are the density, heat capacity, thermal conductivity and temperature of the plate respectively.

\section{NUMERICAL 3D MODELING}

The heat transfer, laminar flow, and electrochemical equations are coupled and solved using the COMSOL program. A two-way approach is used for coupling the 1D electrochemical module with the $3 \mathrm{D}$ thermal module. In this approach, the heat generation rates due to electrochemical reactions, entropy change, and joule heating are calculated locally with the multiphase electrochemical model. Then, the $3 \mathrm{D}$ thermal solver uses the heat generation to find the temperature field in the battery cell. The temperature field is used in a 3D solver while the average of temperature is used to update temperature dependent physiochemical properties in the $1 \mathrm{D}$ electrochemical solver. Heat transfer in solids and battery electrochemical-thermal equations are solved using time-dependent study, and laminar flow equations are solved using the stationary study. The setup consists of a commercially available $20 \mathrm{Ah} \mathrm{LiFePO}_{4}$ cell surrounded by aluminum mini-channel cooling plates. The schematic of the set up as well as the cell and cooling plate dimensions are shown in Figure 1. Each plate has one inlet and one outlet, and all the surfaces and boundaries are open to convective heat fluxes with the heat transfer coefficient of $8 \mathrm{~W} /\left(\mathrm{m}^{2} . \mathrm{K}\right)$. The battery cell is discharged at 30 ${ }^{\circ} \mathrm{C}$ and extreme current rate of $5 \mathrm{C}$ (a C-rate is a measure of the rate at which a battery is charged / discharged relative to its maximum capacity), and inlet coolant temperature is set to ambient temperature. Laminar flow with no shear slip condition on channel wall was applied to the cooing plates. The thermal and electrochemical validation of the model is provided as supplementary material.

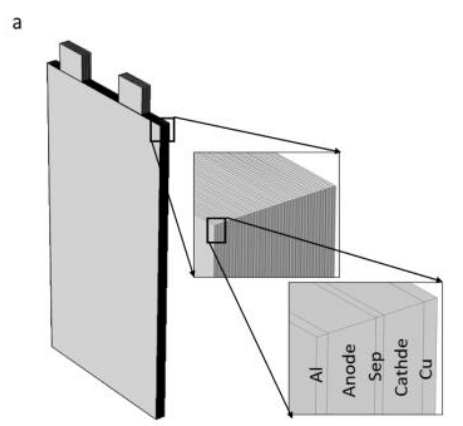

b
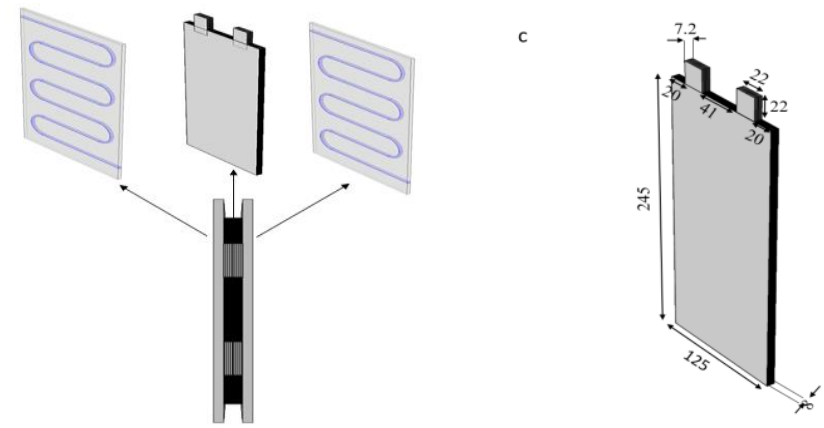

d

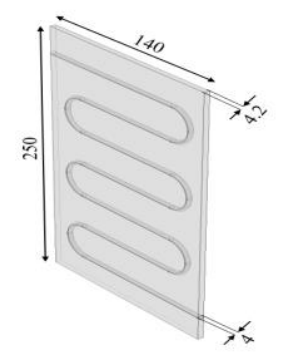

Figure 1. Schematic of (a) the multilayer cell and (b) the cooling system and dimensions of (c) the cell and (d) the cooling system 
Figure 2 shows the computational mesh structure of the single cell with and without a cooling system. A free tetrahedral feature node with the maximum element size of $0.0278 \mathrm{~m}$ and minimum element size of $7.5 \times 10^{-5} \mathrm{~m}$ is used for mesh generation.

a

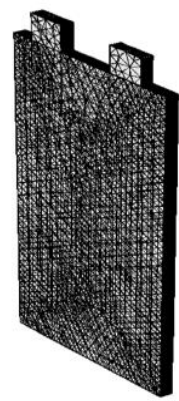

b

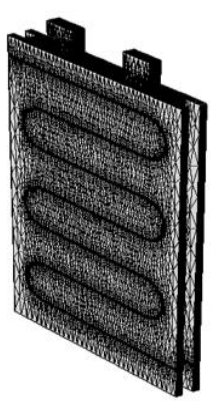

Figure 2. Mesh structure of the cell (a) without and (b) with cooling channels

\section{EXPERIMENTAL PROCEDURE AND MODEL VALIDATION}

Commercially available pouch type fresh $20 \mathrm{Ah}(24.5 \mathrm{~cm}$ x $12.0 \mathrm{~cm}$ x $0.8 \mathrm{~cm})$ lithium cells with $\mathrm{LiFePO}_{4}$ (LFP) cathodes are used for the experiments in this study. Other cell components are graphite as anode material, and an organic electrolyte containing $\mathrm{LiPF}_{6}$ salt dissolved in ethylene carbonate and ethyl methyl carbonate, while the positive current collector is aluminum, and the negative current collector is copper. Neware CT-4004-20V30A-NFA and Neware CT-4008-5V60A-NFA battery testing systems are used for the electrochemical tests, and two channels of the testing units are connected in parallel when the required discharge current is greater than 60A. CA-4008-1U-VT model $\mathrm{N}$ type thermocouples with an accuracy of $\pm 0.1^{\circ} \mathrm{C}$ are used for the surface temperature measurements. All experiments are conducted in a KK 240 TOP+FIT model POL-EKO APARATURA thermal chamber in order to keep the ambient temperature constant. Electrochemical tests used in this study include constant current-constant voltage (CCCV) charging step, followed by a rest period, constant current discharge, and another rest period at constant ambient temperature. Briefly, the cells are first charged in galvanostatic mode at $1 \mathrm{C}$, up to a voltage limit of $3.85 \mathrm{~V}$, and then charged in a potentiostatic mode until the current drops to $300 \mathrm{~mA}$. The cells are then kept at rest for an hour and finally discharged at desired current rates $(0.2 \mathrm{C}, 0.5 \mathrm{C}, 0.7 \mathrm{C}, 1 \mathrm{C}, 2 \mathrm{C}, 3 \mathrm{C}, 4 \mathrm{C}, 5 \mathrm{C})$ until the voltage drops to the pre-determined value. The lowest voltage limit is set to $2.2 \mathrm{~V}$ for safer operating conditions. Data is recorded every five seconds; and a typical cycle can be seen in Figure 3.

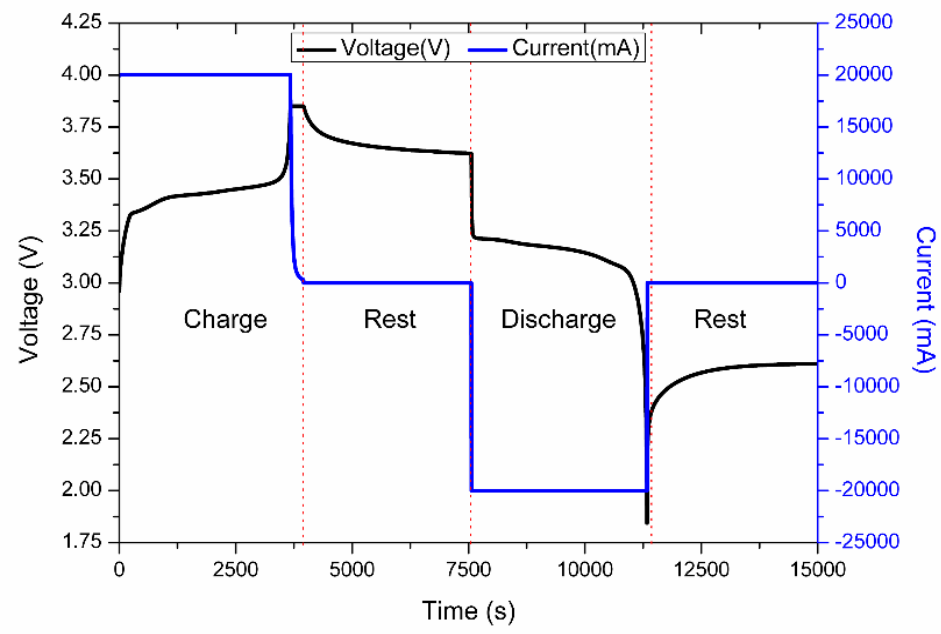

Figure 3. Voltage-current graphic of a cycle at $1 \mathrm{C}$ charge and discharge current rates 
Figure 4 shows the experimental set up for measuring the cell surface temperature profile. Seven thermocouples are placed on the cell surface. Thermocouples 1 and 2 are placed near to positive and negative tabs, 3, 4, 7 are placed on the middle part, and 5 and 6 are placed on the bottom of the cell.
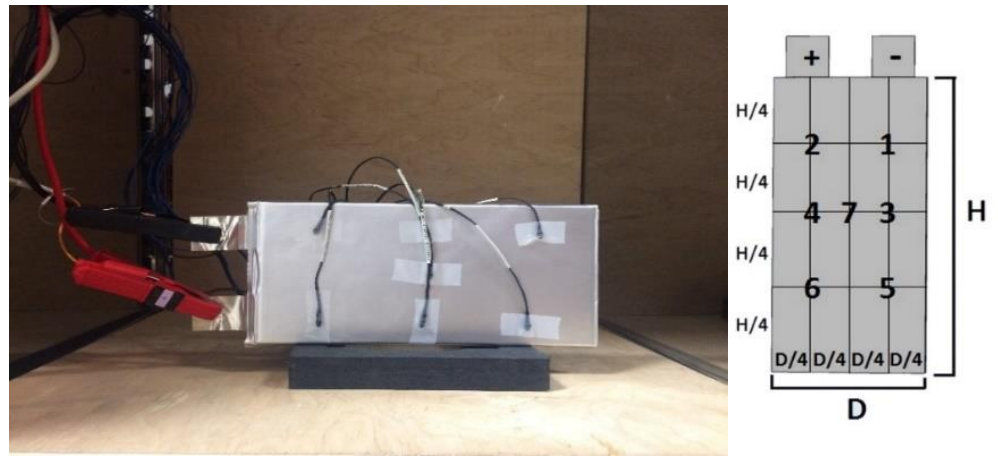

Figure 4. Experimental setup of measuring the cell surface temperature

To validate the developed multilayer model, the electrochemical and thermal results got from the experimental measurements and the model were validated at three discharge current rates $(1 \mathrm{C}, 3 \mathrm{C}$, and $5 \mathrm{C})$. Point 7 which is on the center of the cell surface, is chosen for the thermal validation. Figure 5 shows the voltage and temperature validation of the model at 3 different current rates at $30^{\circ} \mathrm{C}$ :
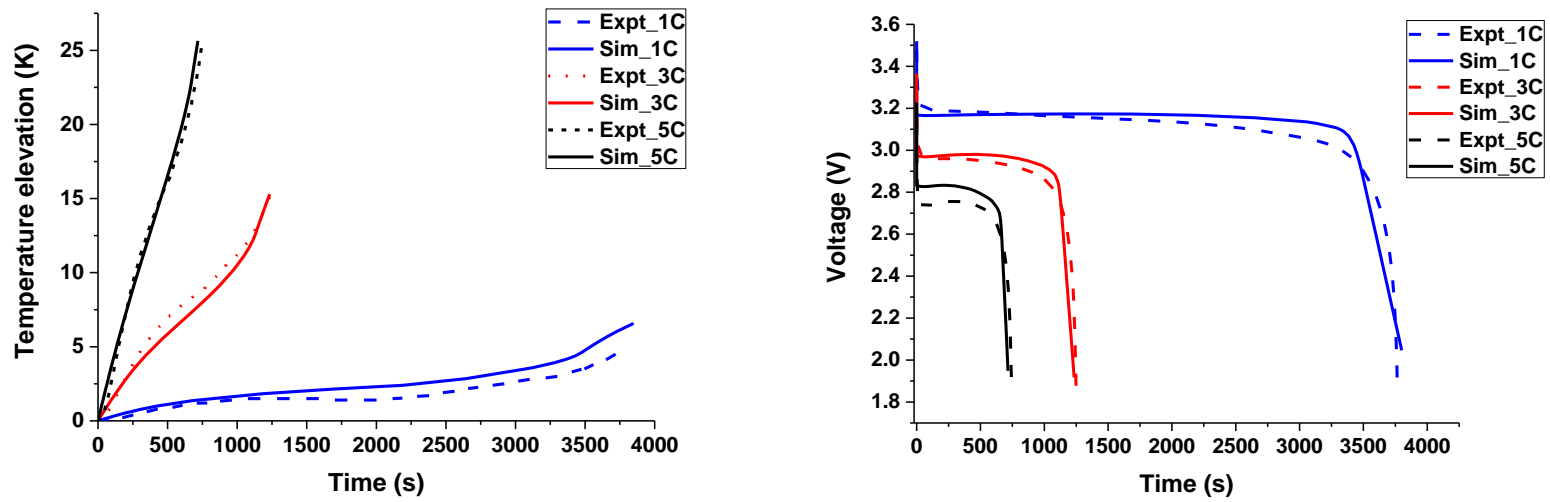

Figure 5. Comparisons of the experimental (Expt) and simulated (Sim) cell surface temperature elevations at different current rates

\section{RESULTS AND DISCUSSION}

Non-uniform temperature profile greatly affects the cell cycle life and leads to the accelerated power and capacity fade [6]. Figure 6 illustrates the temperature profile of the cathode electrode of the first layer (Figure 6-a) and the central layer where the temperature is maximum (Figure 6-b) at the end of 5C discharge without using cooling plates. The temperature on the electrode is as low as $53^{\circ} \mathrm{C}$ and as high as $63^{\circ} \mathrm{C}$. However, olivine systems have major issues with high temperature cycling. If the $\mathrm{LiFePO}_{4}$ cell is discharged above $50^{\circ} \mathrm{C}$, chemical degradation reactions in the cathode increase [33]. As a result, the $\mathrm{LiFePO}_{4}$ electrode forms $\mathrm{Fe}^{+2}$ ions and catalysis the side reactions on the anode, causing the SEI film to increase in thickness [33-35]. This limits $\mathrm{Li}^{+}$diffusion through the thicker SEI layer and increases the bulk and SEI resistances. Consequently, power and capacity losses at high temperatures $\left(>50^{\circ} \mathrm{C}\right)$ are unavoidable. Moreover, temperature non-uniformity is more harmful for the anode and the cathode electrodes which contain active material. When the cell is discharged at $5 \mathrm{C}$, ohmic heat becomes dominant and the regions close to the 
tab heat more quickly [32]. The temperature gradients on the first and central cathode electrodes are $8.59{ }^{\circ} \mathrm{C}$ and 9.60 ${ }^{\circ} \mathrm{C}$, respectively, and result in localized aging.

In this work, a series of simulations have been conducted to investigate the effects of design parameters such as a cooling fluid, a number of channel passes, channel width, and inlet mass flow rates on cooling performance of the cooling system. All the simulations were done at ambient temperature of $30^{\circ} \mathrm{C}$ and $5 \mathrm{C}$ discharge. To evaluate cooling performance, three parameters were considered: maximum temperature rise ( $\left.\mathrm{T}_{\max }\right)$ on cell surface, maximum temperature difference $(\Delta T)$ on cell surface, and pressure difference between the inlet and outlet of the cooling plate. The aim was to achieve uniform temperature profile by minimizing the temperature gradient $(\Delta \mathrm{T})$. However, pressure difference $(\Delta \mathrm{P})$ had to be considered while minimizing $\Delta \mathrm{T}$ because higher $\Delta \mathrm{P}$ results in higher power consumption which is not favorable from an economical viewpoint. The ideal power consumption used for the coolant driving force can be calculated using Equation 23:[25]

$$
\text { Power }=\sum_{i}^{n} \Delta P_{i} V_{i}
$$

Where, $\Delta P_{i}$ is the pressure drop, $V_{i}$ is the volumetric flow rate in the coolant channel, and $i$ represents the coolant channel number. Overall, the lower the $\Delta \mathrm{T}$ and the $\Delta \mathrm{P}$, the better the cooling performance is.

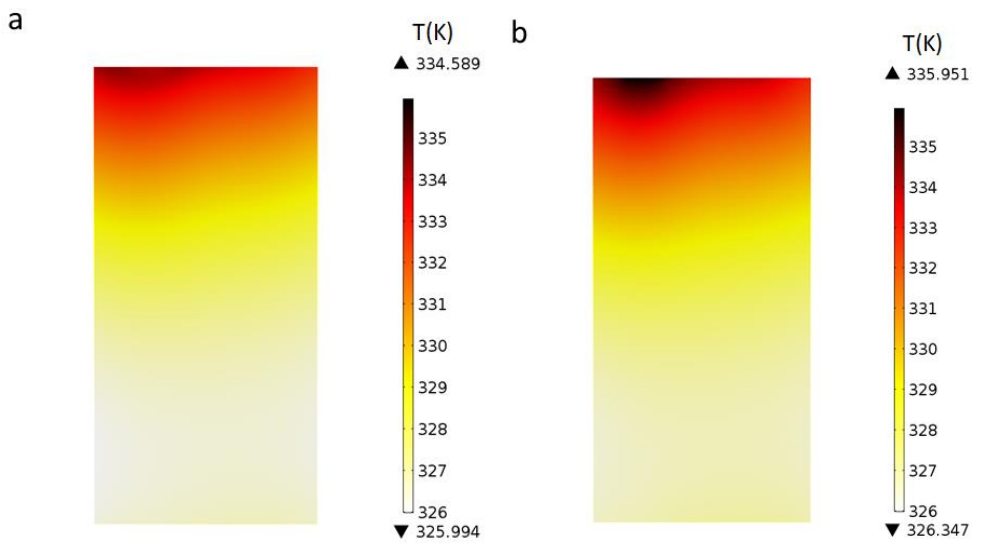

Figure 6. Temperature profile on the cathode of the (a) first layer and (b) of the central layer without cooling system at $5{ }^{\circ} \mathrm{C}$

\section{EFFECTS OF INLET FLOW RATE}

In the first section, the effects of inlet mass flow rate on cooling performance were studied. In this approach, the coolant type, channel width, and number of passes are kept as fixed parameters while the inlet mass flow rate is chosen as the variable parameter. The inlet mass flow rate is changed from $0.1 \mathrm{~g} / \mathrm{s}$ to $10 \mathrm{~g} / \mathrm{s}$. Figure 7 shows the maximum temperature rise on the surface of the cells with and without a cooling system under different inlet mass flow rates. Without any cooling plates, the maximum temperature rise was approximately $33^{\circ} \mathrm{C}$. High convective heat transfer coefficient of water in conjunction with the high thermal conductivity of the aluminum plates results in significant heat flux and makes the maximum temperature rise fall from $33^{\circ} \mathrm{C}$ to $13.64^{\circ} \mathrm{C}$ when the inlet mass flow rate is set to $0.1 \mathrm{~g} / \mathrm{s}$. If the inlet mass flow rate increases, the cooling performance improves. The maximum surface temperature rises are calculated as $10.18{ }^{\circ} \mathrm{C}, 8.58,6.21{ }^{\circ} \mathrm{C}$, and $5.89^{\circ} \mathrm{C}$ when the inlet mass flow rates are set to 0.5 $\mathrm{g} / \mathrm{s}, 1 \mathrm{~g} / \mathrm{s}, 5 \mathrm{~g} / \mathrm{s}$, and $10 \mathrm{~g} / \mathrm{s}$ respectively (Figure 7). However, higher inlet mass flow rate will result in higher pressure drop and consequently higher pump power consumption. Therefore, the cost of the power needed to pump the coolant through the channels should also be considered in optimization of the battery temperature.

Table 2 lists the temperature gradient $(\Delta \mathrm{T})$ and pressure drop $(\Delta \mathrm{P})$ under different flow rates. Higher flow rates result in lower temperature gradients and higher pressure drops. Thermal performance for $\dot{m}=5 \mathrm{~g} / \mathrm{s}$ and $\dot{m}=10$ 
$\mathrm{g} / \mathrm{s}$ is quite close while the pressure drops for $\dot{m}=5 \mathrm{~g} / \mathrm{s}$ is significantly lower than $\dot{m}=10 \mathrm{~g} / \mathrm{s}$. Therefore, by setting the inlet mass flow rate to $5 \mathrm{~g} / \mathrm{s}$, the best cooling performance can be obtained at $5{ }^{\circ} \mathrm{C}$ discharge.

Table 3. $\Delta \mathrm{T}$ and $\Delta \mathrm{P}$ values at different mass flow rates

\begin{tabular}{clc}
\hline Mass Flow Rate $(\mathrm{g} / \mathrm{s})$ & $\Delta \mathrm{T}(\mathrm{K})$ & $\Delta \mathrm{P}(\mathrm{KPa})$ \\
\hline No cooling & 7.26 & - \\
0.1 & 1.43 & 0.011 \\
0.5 & 1.18 & 0.06 \\
1 & 1.01 & 0.12 \\
5 & 0.72 & 1.75 \\
10 & 0.62 & 2.5 \\
\hline
\end{tabular}

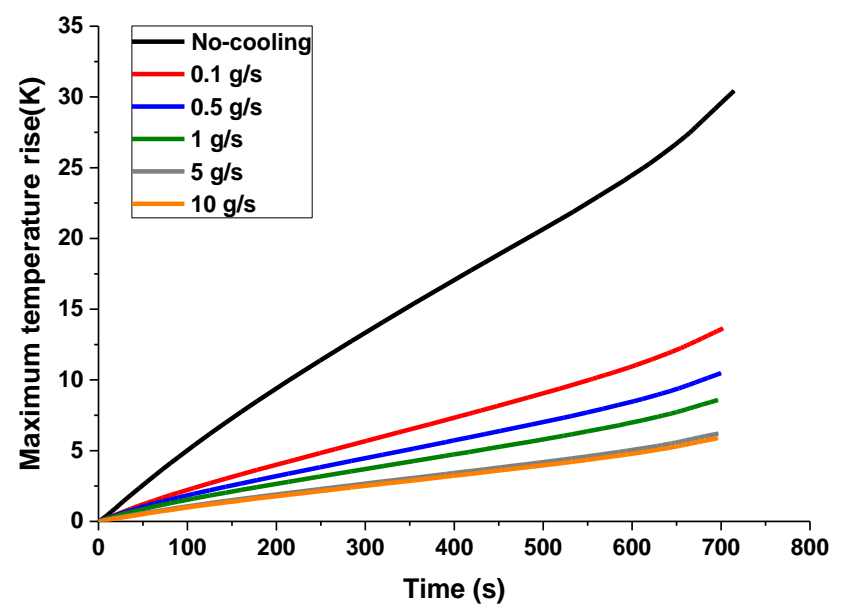

Figure 7. Maximum temperature rise $(\mathrm{K})$ under different flow rates at $5{ }^{\circ} \mathrm{C}$ and $30{ }^{\circ} \mathrm{C}$

\section{EFFECTS OF CHANNEL WIDTH}

In the second section, the effects of channel width on cooling performance were investigated. In this approach, three types of channels with the radius of $1 \mathrm{~mm}, 1.5 \mathrm{~mm}$, and $2 \mathrm{~mm}$ were considered. The inlet mass flow rate of water was set to $1 \mathrm{~g} / \mathrm{s}$ and plate with seven channel passes was chosen. Figure 8 illustrates the maximum temperature rise on the cell surface considering the cooling plates with different channel width. The maximum temperature rise decreases from $9.84{ }^{\circ} \mathrm{C}$ to $8.58{ }^{\circ} \mathrm{C}$ when the channel width was changed from $1 \mathrm{~mm}$ to $2 \mathrm{~mm}$. This could be explained by the increased heat transfer area. Consequently, more heat is dissipated using the plate with wider channels. Furthermore, wider channel widths result in more uniform temperature distribution and lower pressure drop and therefore lower cost. Table 3 lists the temperature gradients $(\Delta \mathrm{T})$ on the cell surface and the pressure drops $(\Delta \mathrm{P})$ for different channel widths. $\Delta \mathrm{T}$ decreases from $1.93{ }^{\circ} \mathrm{C}$ to $1.01{ }^{\circ} \mathrm{C}$ and $\Delta \mathrm{P}$ reduces from $2.13 \mathrm{KPa}$ to $0.12 \mathrm{KPa}$ as channel width enlarges from $1 \mathrm{~mm}$ to $2 \mathrm{~mm}$, respectively. Overall, wider channels lead to better cooling performance. However, thicker plates are needed to carve wider channels which adds extra mass to battery modules and packs.

Table 4. $\Delta \mathrm{T}$ and $\Delta \mathrm{P}$ values at different channel widths

\begin{tabular}{ccc}
\hline Channel radius $(\mathrm{mm})$ & $\Delta \mathrm{T}(\mathrm{K})$ & $\Delta \mathrm{P}(\mathrm{KPa})$ \\
\hline 1 & 1.93 & 2.13 \\
1.5 & 1.58 & 0.91 \\
2 & 1.01 & 0.12 \\
\hline
\end{tabular}




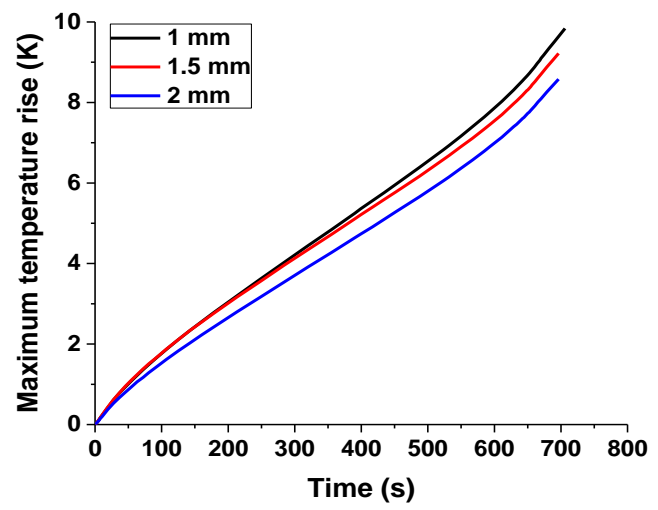

Figure 8. Maximum temperature rise $(\mathrm{K})$ for plates with different channel width at $5{ }^{\circ} \mathrm{C}$

\section{EFFECTS OF NUMBER OF CHANNEL PASSES}

The number of channel passes influences the cooling performance and pressure drop of the thermal management system. Figure 9 shows the schematic of cooling plates with three channel passes (Figure 9-a) and eleven channel passes (Figure 9-b). It is clear that heat transfer area increases as the number of passes increases which results in more heat dissipation. However, increasing the number of passes results in fabrication complexity, higher cost, and higher pressure drop. Figure 9-c shows maximum temperature rises on cell surface using plates with different number of channel passes. Water with mass flow rate of $1 \mathrm{~g} / \mathrm{s}$ is pumped through the channels with radius of $2 \mathrm{~mm}$. Maximum temperature on cell surface rises to $14.35,11.98,9.28,8.89$, and $8.58{ }^{\circ} \mathrm{C}$ as plates with $3,5,7,9$, and 11 channel passes are used, respectively. It can be observed that as the number of passes increases, the impact on maximum temperature rise decreases. In other words, plates with 7, 9, and 11 channels passes show almost the same impact on maximum temperature rise.

a

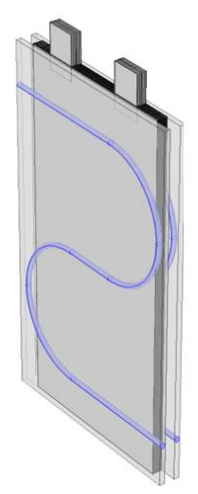

b

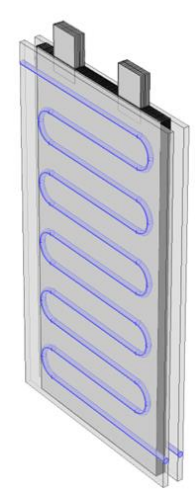

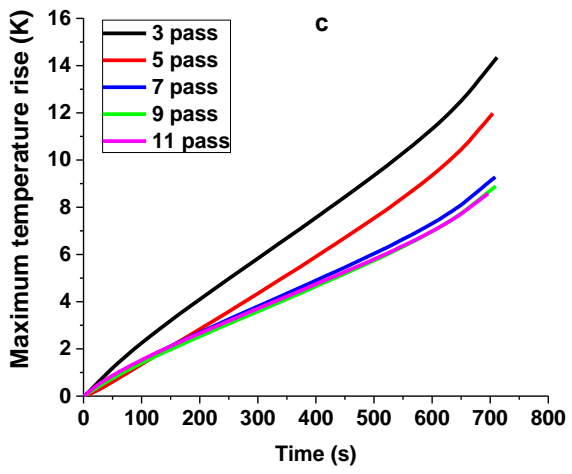

Figure 9. Schematic of cooling system with (a) 3 channel pass and (b) 11 channel passes and (c) maximum temperature rises for plate with different channel passes

Temperature differences $(\Delta \mathrm{T})$ on cell surface and pressure drops $(\Delta \mathrm{P})$ are listed in Table 5. Plates with a greater number of channel passes show better cooling performance. However, $\Delta \mathrm{T}$ is less influenced as the number of passes increases. On the other hand, $\Delta \mathrm{P}$ values are highly influenced by the number of passes. When the inlet flow rate is set to $1 \mathrm{~g} / \mathrm{s}$, the difference of $\Delta \mathrm{P}$ values between 3 and 11 passes become $0.173 \mathrm{KPa}$. The difference increases even further at higher flow rates. According to Equation 23, even a small pressure drops results in big difference in power consumption. Therefore, choosing the optimum case is necessary. Overall, plate with 7 number of passes show optimum results considering the $\mathrm{T}_{\max }, \Delta \mathrm{T}$, and $\Delta \mathrm{P}$ values. 
Journal of Thermal Engineering, Research Article, Vol. 6, No. 6, Special Issue 12, pp. 257-271, December, 2020

Table 5. $\Delta \mathrm{T}$ and $\Delta \mathrm{P}$ values for plat with different channel passes

\begin{tabular}{cll}
\hline \# of channel passes & $\Delta \mathrm{T}(\mathrm{K})$ & $\Delta \mathrm{P}(\mathrm{KPa})$ \\
\hline 3 & 1.63 & 0.057 \\
5 & 1.30 & 0.083 \\
7 & 1.01 & 0.12 \\
9 & 0.86 & 0.17 \\
11 & 0.75 & 0.23 \\
\hline
\end{tabular}

\section{EFFECTS OF COOLING MEDIUM}

The type of cooling medium greatly affects the performance and cost of the thermal management system[25]. Heat transfer rate between the cooling plates and medium highly depends on the physical and thermal properties of the medium such as viscosity, thermal conductivity, and density. The heat transfer medium could be chosen according to the type of coolant system. Cooling performance of the water-cooling system (WCS) and the air-cooling system (ACS) were compared in our model. In this approach, plates with channel width of $2 \mathrm{~mm}$ and 7 passes were used in this section. Figure 10 shows the cooling performance of the WCS and ACS at three inlet mass flow rates. The maximum temperature rises to $14.85^{\circ} \mathrm{C}$ for the ACS and $13.64{ }^{\circ} \mathrm{C}$ for the WCS at the end of the discharge when the inlet mass flow rate is set to $0.1 \mathrm{~g} / \mathrm{s}$ (Figure 10-a). By increasing the mass flow rate, the difference between cooling performances of systems become more distinctive. At $\dot{m}=1 \mathrm{~g} / \mathrm{s}$, the maximum temperature drops $5.30^{\circ} \mathrm{C}$ more when the WCS is considered (Figure 10-b). Similarly, at $\dot{m}=10 \mathrm{~g} / \mathrm{s}$, the WCS cools down the cell $4.1^{\circ} \mathrm{C}$ better than the ACS (Figure 10-c). Furthermore, the cooling performance of the WCS at $\dot{m}=1 \mathrm{~g} / \mathrm{s}$ is better than the cooling performance of the ACS at $\dot{m}=10 \mathrm{~g} / \mathrm{s}$ (Figure 10-b, c). This is due to the higher thermal conductivity of water with respect to air.
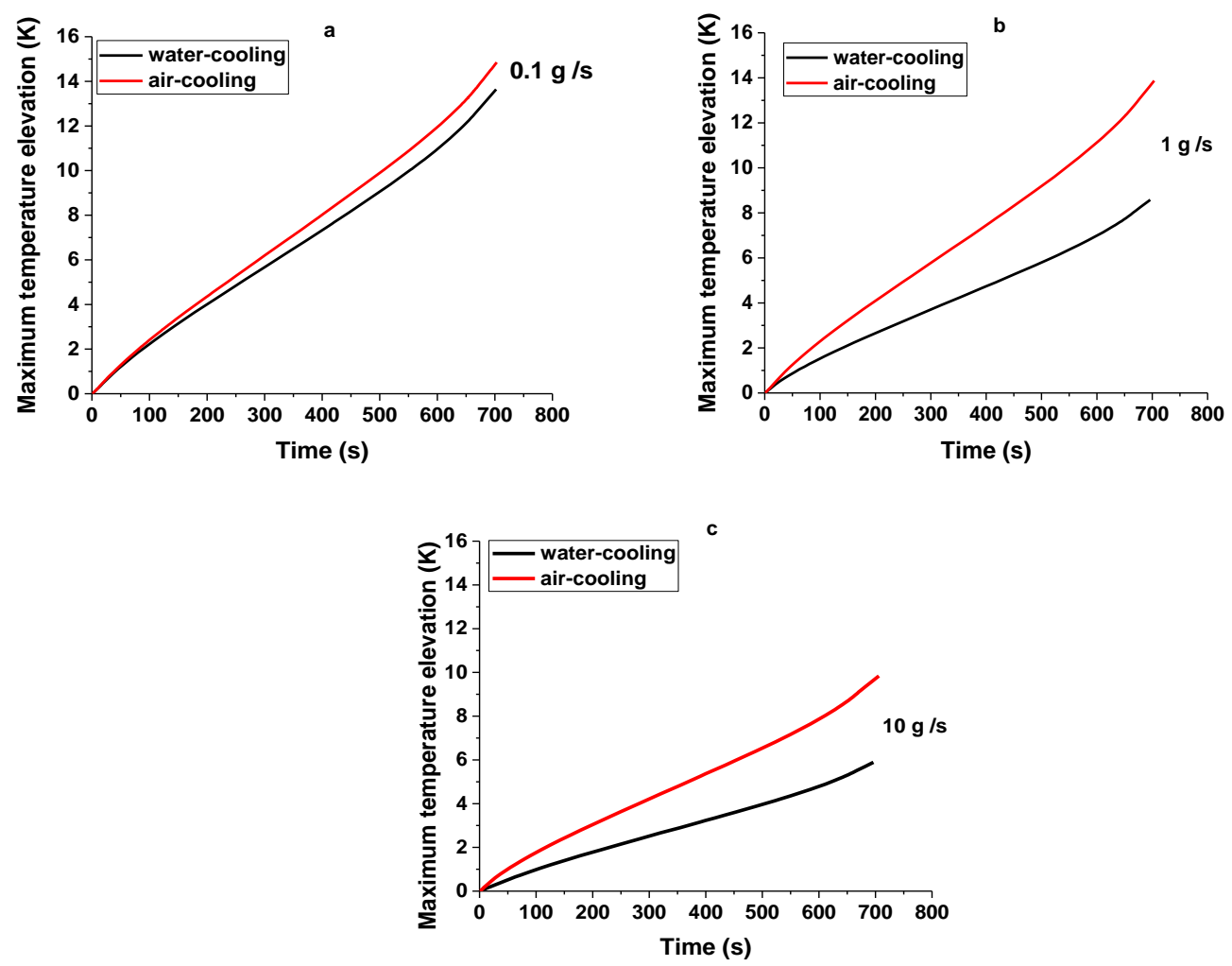

Figure 10. Comparison of maximum temperature elevations $(\mathrm{k})$ on the surface of cells with the air cooling versus the water-cooling system at (a) $\dot{m}=0.1 \mathrm{~g} / \mathrm{s}$, (b) $\dot{m}=1 \mathrm{~g} / \mathrm{s}$, and (c) $\dot{m}=10 \mathrm{~g} / \mathrm{s}$ 
The temperature profile of the central cathode electrode using the WCA and the ACS is shown at two different flow rates in Figure 11. Mass flow rate significantly affects the thermal performance of the ACS and WCA. Therefore, two extreme cases were selected: the minimum flow rate $(\dot{m}=0.1 \mathrm{~g} / \mathrm{s})$ and the maximum flow rate $(\dot{m}=10 \mathrm{~g} / \mathrm{s})$. At $\dot{m}=0.1 \mathrm{~g} / \mathrm{s}$, the $\mathrm{T}_{\max }$ and $\Delta T$ values are $319.413 \mathrm{~K}$ and $1.99 \mathrm{~K}$ when the ACS is used, and they are $318.149 \mathrm{~K}$ and 1.8 $\mathrm{K}$ when the WCS is used, respectively. Similarly, at $\dot{m}=10 \mathrm{~g} / \mathrm{s} \mathrm{T}_{\max }$ and $\Delta T$ values are $313.99 \mathrm{k}$ and $1.323 \mathrm{~K}$ for the ACS, and they are $311.198 \mathrm{~K}$ and $1.172 \mathrm{~K}$ for the WCS. Considering the thermal behavior of the cell without a cooling system, the ACS offers $48.9 \%$ and $69.75 \%$ efficiency on dropping the $\mathrm{T}_{\max }$ and $\Delta T$ when $\dot{m}=0.1 \mathrm{~g} / \mathrm{s}$, and it offers $65.9 \%$ and $79.8 \%$ efficiency when $\dot{m}=10 \mathrm{~g} / \mathrm{s}$. Similarly, the WCS offers $52.9 \%$ and $72.64 \%$ efficiency on dropping the $\mathrm{T}_{\max }$ and $\Delta T$ when $\dot{m}=0.1 \mathrm{~g} / \mathrm{s}$, and it offers $74.7 \%$ and $82.2 \%$ efficiency when $\dot{m}=10 \mathrm{~g} / \mathrm{s}$. Overall, the WCS shows better performance compared to the ACS at same mass flow rates.

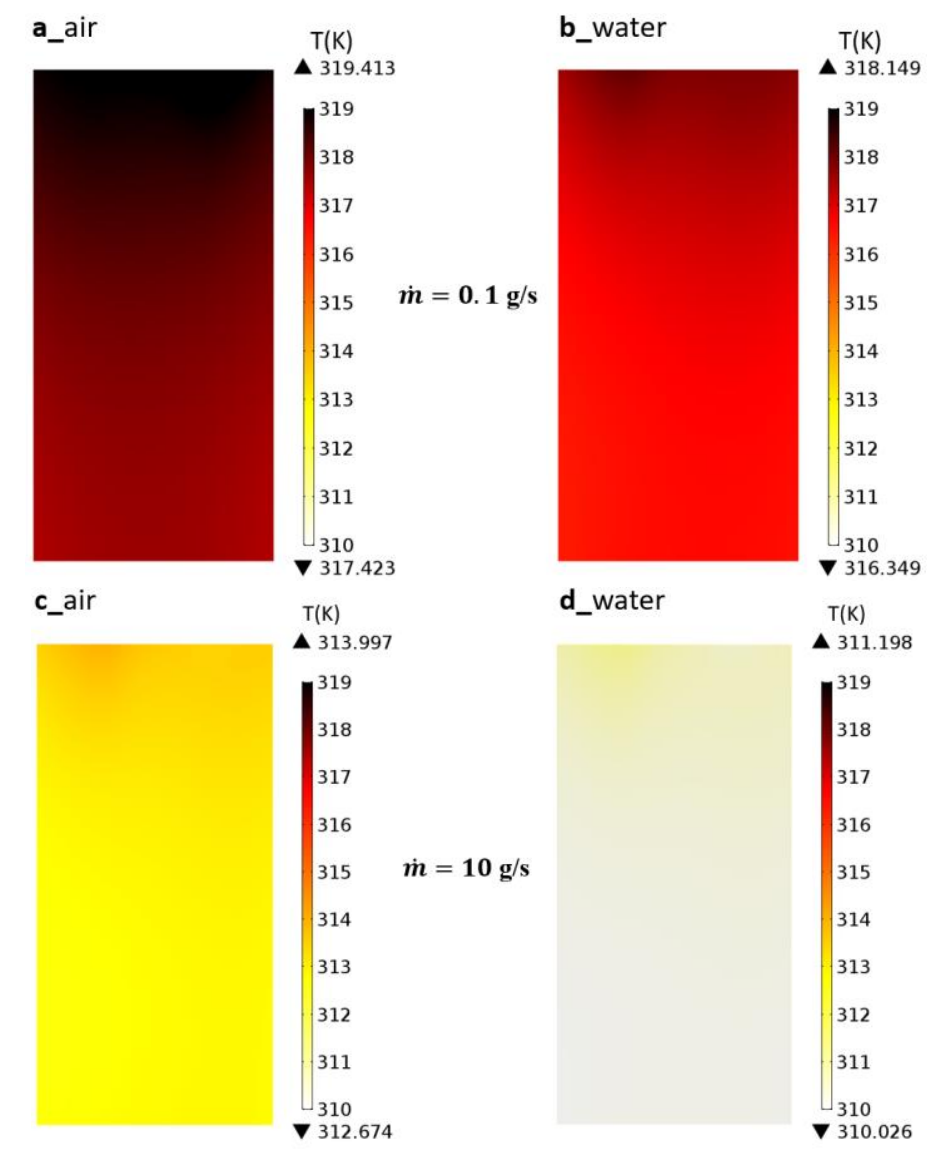

Figure 11. Comparison of the cell internal (cathode from layer 10) temperature (K) profiles when $(a, c)$ the ACS is used and $(b, d)$ the WCS is used

By increasing the mass flow rate of the cooling medium, the average temperature of the cell can be dropped further. Also, increased mass flow rate will result in a more uniform temperature profile which is the main aim of this study. However, with increasing the coolant flow rate, the power used to pump the coolant increases dramatically (equation 23). Table 6 and Table 7 lists the volumetric flow rates $(\dot{V})$, pressure drop $(\Delta P)$, and total power consumption values for WCA and ACS at different inlet mass flow rates, respectively. Volumetric flow rate $(\dot{V})$ can be obtained by dividing the mass flow rate $(\dot{m})$ by the density $(\rho)$. At $30^{\circ} \mathrm{C}$ the density of water and air are considered as 995.6 and $1.164 \mathrm{Kg} / \mathrm{m}^{3}$ [36]. This means that at same mass flow rates, $\dot{V}$ of air becomes approximately 885 times $\dot{V}$ of water leading to a great pressure drop in the ACS. As listed in Table 6 and Table 7, the pressure drop of the ACS is 40.9, 267.5 , and 474.9 times pressure drop of the WCS at $\dot{m}=0.1, \dot{m}=1$, and $\dot{m}=10 \mathrm{~g} / \mathrm{s}$. Higher volumetric flow rates 
and pressure drop values in air cooling system leads to huge power loss since it is obtained by multiplying $\dot{V}$ and $\Delta \mathrm{P}$ (Equation 23). For instance, at $\dot{m}=10 \mathrm{~g} / \mathrm{s}$, power loss of the WCS is $0.025 \mathrm{~W}$ compared to power loss of the ACS which is $10180 \mathrm{~W}$.

Table 6. $\Delta \mathrm{P}, \dot{\mathrm{V}}$, and Power Loss values for water cooling system

\begin{tabular}{lclr}
\hline$\dot{m}(\mathrm{~g} / \mathrm{s})$ & $\Delta \mathrm{P}(\mathrm{KPa})$ & $\dot{\boldsymbol{V}}(\mathrm{mL} / \mathrm{s})$ & Power $(\mathrm{W})$ \\
\hline 0.1 & 0.011 & 0.1005 & $1.11 \mathrm{e}-6$ \\
1 & 0.120 & 1.005 & $1.21 \mathrm{e}-4$ \\
10 & 2.495 & 10.05 & 0.025 \\
\hline
\end{tabular}

Table 7. $\Delta \mathrm{P}, \dot{\mathrm{V}}$, and Power Loss values for air cooling system

\begin{tabular}{lccc}
\hline$\dot{m}(\mathrm{~g} / \mathrm{s})$ & $\Delta \mathrm{P}(\mathrm{KPa})$ & $\dot{\boldsymbol{V}}(\mathrm{mL} / \mathrm{s})$ & Power $(\mathrm{W})$ \\
\hline 0.1 & 0.450 & 85.91 & 0.038 \\
1 & 32.11 & 859.1 & 27.586 \\
10 & 1185 & 8591 & 10180 \\
\hline
\end{tabular}

\section{CONCLUSION}

By using a proper thermal management system, thermal issues of the Li-ion battery can be controlled. Temperature profile of the Li-ion cells plays significant role on the performance, safety, and cycle life of the battery. That is why a little temperature gradient can lead to great loss in the performances of battery packs. In this work, the effects of a cooling design parameters on thermal behavior of the multilayer LiFePO4 cell were studied. Both surface and internal temperature profiles of a single cell are investigated with and without cooling systems. The main conclusions of this study are summarized as follows:

1. Inlet mass flow rate is the main effective parameter in cooling performance.

2. Channel width has more influence on pressure drop than temperature drop.

3. Plate with seven channel passes show superior cooling performance considering both $\Delta \mathrm{T}$ and $\Delta \mathrm{P}$.

4. At higher current rates, air-cooling system leads to great power consumption and water-cooling system is recommended.

\section{NOMENCLATURE}

$a_{s}$

$A_{\text {tab }}$

$C_{d l}$

$c_{e}$

$C_{p}$

$c_{S}$

$c_{s, 0}$

$c_{s, \max }$

$c_{s, \text { sur }}$

$D_{e}$

$D_{s}$

$f$

F

$h$

$i_{0}$

$i_{a p p}$

$i_{l o c}$
Electrode specific surface area, $\mathrm{m}^{-1}$

Cross section of the tab, $\mathrm{m}^{2}$

Electrical double layer capacitance, $\mathrm{F} / \mathrm{m}^{2}$

Lithium concentration in electrolyte, $\mathrm{mol} / \mathrm{m}^{3}$

Specific heat, J/kg.K

Lithium concentration in solid, $\mathrm{mol} / \mathrm{m}^{3}$

Initial lithium concentration in solid, $\mathrm{mol} / \mathrm{m}^{3}$

Max li ion concentration in solid, $\mathrm{mol} / \mathrm{m}^{3}$

Surface concentration of lithium in the active material, mol. $\mathrm{m}^{3}$

Diffusion coefficient of Li ion in electrolyte, $\mathrm{m}^{2} / \mathrm{s}$

Diffusion coefficient of $\mathrm{Li}$ ion in solid, $\mathrm{m}^{2} / \mathrm{s}$

Average molar activity coefficient

Faraday's constant $(96,487 \mathrm{C} / \mathrm{mol})$

Convective heat transfer coefficient, $\mathrm{W} / \mathrm{m}^{2} . \mathrm{K}$

Exchange current density, $\mathrm{A} / \mathrm{m}^{2}$

Total applied current density, $\mathrm{A} / \mathrm{m}^{2}$

Local working current density of the cell unit, $\mathrm{A} / \mathrm{m}^{2}$ 
Journal of Thermal Engineering, Research Article, Vol. 6, No. 6, Special Issue 12, pp. 257-271,

December, 2020

$\begin{array}{ll}i_{N} & \text { Normal inward current density through the electrode/ } \\ k & \text { Reaction rate constant, } \mathrm{m}^{2.5} / \mathrm{mol}^{0.5} . \mathrm{s} \\ L_{b a t t} & \text { Battery cell thickness, } \mathrm{m} \\ N & \text { Total number of cell layers } \\ r & \text { Radios of electrode particle, } \mathrm{m} \\ R & \text { Universal gas coefficient, } 8.314 \mathrm{~J} / \mathrm{mol} . \mathrm{K} \\ t & \text { Time, } \mathrm{s} \\ T & \text { Absolute temperature, } \mathrm{K} \\ t_{+} & \text {Transferring number of } \mathrm{Li}^{+} \\ U_{e q} & \text { Open circuit potential, } \mathrm{V} \\ & \\ \mathrm{Greek} \text { symbols } & \\ \alpha_{a} & \text { Anodic transfer coefficient } \\ \alpha_{c} & \text { Cathodic transfer coefficient } \\ \varepsilon_{e} & \text { Volume fraction of the fillers } \\ \kappa_{e f f} & \text { Effective ionic conductivity of the electrolyte }(\mathrm{S} / \mathrm{m}) \\ \sigma_{e} & \text { Ionic conductivity of electrolyte }(\mathrm{S} / \mathrm{m}) \\ \sigma_{s} & \text { Electronic conductivity of the solid phase }(\mathrm{S} / \mathrm{m}) \\ \lambda & \text { Thermal conductivity (W/m.K) } \\ \phi_{e} & \text { Electrolyte-phase potential (V) } \\ \phi_{s} & \text { Solid-phase potential (V) } \\ \text { Subscripts } & \\ 0 & \text { Initial value } \\ c c & \text { Current collector } \\ e f f & \text { Efficient } \\ i & \text { Indicator (i = pe, ne) } \\ e & \text { Electrolyte } \\ n e & \text { Negative electrode } \\ m a x & \text { Maximum } \\ p e & \text { Positive electrode } \\ \mathrm{s} & \text { Solid } \\ s e p & \text { Separator } \\ & \end{array}$

ACKNOWLEDGMENTS: The authors acknowledge a financial support from the Scientific and Technological Research Council of Turkey (TUBITAK) under Grant No.214M310.

\section{REFERENCES}

[1] Chouhan, N.S. and M. Ferdowsi. Review of energy storage systems. in North American Power Symposium (NAPS), 2009. 2009. IEEE.

[2] Barton, J.P. and D.G. Infield, Energy storage and its use with intermittent renewable energy. IEEE transactions on energy conversion, 2004. 19(2): p. 441-448.

[3] Maheri, A., Incorporating End-User Requirements in Design of Hybrid Renewable Energy Systems. Journal of Thermal Engineering, 2016. 2(3): p. 780-785.

[4] Boyes, J.D. and N.H. Clark. Technologies for energy storage. Flywheels and super conducting magnetic energy storage. in Power Engineering Society Summer Meeting, 2000. IEEE. 2000. IEEE.

[5] Maheri, A., Effect of dispatch strategy on the performance of hybrid wind-PV battery-diesel-fuel cell systems. 2. Journal of Thermal Engineering, 2016. 4(4): p. 820-825. 
[6] Song, W., et al., Non-uniform effect on the thermal/aging performance of Lithium-ion pouch battery. Applied Thermal Engineering, 2018. 128: p. 1165-1174.

[7] Tarascon, J.-M. and M. Armand, Issues and challenges facing rechargeable lithium batteries, in Materials For Sustainable Energy: A Collection of Peer-Reviewed Research and Review Articles from Nature Publishing Group. 2011, World Scientific. p. 171-179.

[8] Alipour, M., et al., Performance of high capacity Li-ion pouch cells over wide range of operating temperatures and discharge rates. Journal of Electroanalytical Chemistry, 2020. 860: p. 113903.

[9] Bandhauer, T.M., S. Garimella, and T.F. Fuller, A Critical Review of Thermal Issues in Lithium-Ion Batteries. Journal of the Electrochemical Society, 2011. 158(3): p. R1-R25.

[10] Gu, W.B. and C.Y. Wang, Thermal-electrochemical modeling of battery systems. Journal of the Electrochemical Society, 2000. 147(8): p. 2910-2922.

[11] Situ, W.F., et al., Effect of high temperature environment on the performance of LiNi0.5Co0.2 Mn0.3O2 battery. International Journal of Heat and Mass Transfer, 2017. 104: p. 743-748.

[12] Chen, S.C., C.C. Wan, and Y.Y. Wang, Thermal analysis of lithium-ion batteries. Journal of Power Sources, 2005. 140(1): p. 111-124.

[13] Chen, M.B., et al., A multilayer electro-thermal model of pouch battery during normal discharge and internal short circuit process. Applied Thermal Engineering, 2017. 120: p. 506-516.

[14] Qian, Z., Y.M. Li, and Z.H. Rao, Thermal performance of lithium-ion battery thermal management system by using mini-channel cooling. Energy Conversion and Management, 2016. 126: p. 622-631.

[15] Chen, D.F., et al., Comparison of different cooling methods for lithium ion battery cells. Applied Thermal Engineering, 2016. 94: p. 846-854.

[16] An, Z.J., et al., A Review on Lithium-ion Power Battery Thermal Management Technologies and Thermal Safety. Journal of Thermal Science, 2017. 26(5): p. 391-412.

[17] Zhao, R., J. Liu, and J. Gu, The effects of electrode thickness on the electrochemical and thermal characteristics of lithium ion battery. Applied Energy, 2015. 139: p. 220-229.

[18] An, Z., et al., A review on lithium-ion power battery thermal management technologies and thermal safety. Journal of Thermal Science, 2017. 26(5): p. 391-412.

[19] Zhao, R., et al., A review of thermal performance improving methods of lithium ion battery: electrode modification and thermal management system. Journal of Power Sources, 2015. 299: p. 557-577.

[20] de Hoog, J., et al., Combining an Electrothermal and Impedance Aging Model to Investigate Thermal Degradation Caused by Fast Charging. Energies, 2018. 11(4): p. 804.

[21] Jaguemont, J., et al., Streamline three-dimensional thermal model of a lithium titanate pouch cell battery in extreme temperature conditions with module simulation. Journal of Power Sources, 2017. 367: p. 24-33.

[22] Shabani, B. and M. Biju, Theoretical modelling methods for thermal management of batteries. Energies, 2015. 8(9): p. 10153-10177.

[23] Ping, P., et al., Modelling electro-thermal response of lithium-ion batteries from normal to abuse conditions. Applied Energy, 2017. 205: p. 1327-1344.

[24] Liu, R., et al., Numerical investigation of thermal behaviors in lithium-ion battery stack discharge. Applied Energy, 2014. 132: p. 288-297.

[25] Chen, D., et al., Comparison of different cooling methods for lithium ion battery cells. Applied Thermal Engineering, 2016. 94: p. 846-854.

[26] Qian, Z., Y. Li, and Z. Rao, Thermal performance of lithium-ion battery thermal management system by using mini-channel cooling. Energy Conversion and Management, 2016. 126: p. 622-631.

[27] Chen, M., et al., A multilayer electro-thermal model of pouch battery during normal discharge and internal short circuit process. Applied Thermal Engineering, 2017. 120: p. 506-516.

[28] Goutam, S., et al., Three-dimensional electro-thermal model of Li-ion pouch cell: Analysis and comparison of cell design factors and model assumptions. Applied Thermal Engineering, 2017. 126: p. 796-808.

[29] Alipour, M., E. Esen, and R. Kizilel, Investigation of 3-D multilayer approach in predicting the thermal behavior of 20Ah Li-ion cells. Applied Thermal Engineering, 2019.

[30] Ye, Y., et al., Effect of thermal contact resistances on fast charging of large format lithium ion batteries. Electrochimica Acta, 2014. 134: p. 327-337.

[31] Samba, A., et al., Impact of tab location on large format lithium-ion pouch cell based on fully coupled treedimensional electrochemical-thermal modeling. Electrochimica Acta, 2014. 147: p. 319-329.

[32] Xu, M., et al., A pseudo three-dimensional electrochemical-thermal model of a prismatic LiFePO4 battery during discharge process. Energy, 2015. 80: p. 303-317. 
Journal of Thermal Engineering, Research Article, Vol. 6, No. 6, Special Issue 12, pp. 257-271, December, 2020

[33] Waldmann, T., et al., Temperature dependent ageing mechanisms in Lithium-ion batteries-A Post-Mortem study. Journal of Power Sources, 2014. 262: p. 129-135.

[34] Amine, K., J. Liu, and I. Belharouak, High-temperature storage and cycling of C-LiFePO4/graphite Li-ion cells. Electrochemistry communications, 2005. 7(7): p. 669-673.

[35] Deshpande, R., et al., Battery cycle life prediction with coupled chemical degradation and fatigue mechanics. Journal of the Electrochemical Society, 2012. 159(10): p. A1730-A1738.

[36] Tanaka, M., et al., Recommended table for the density of water between $0 \mathrm{C}$ and $40 \mathrm{C}$ based on recent experimental reports. Metrologia, 2001. 38(4): p. 301. 